\title{
Influence of nutrient loading on reactions upon frost and drought stress of Rosa majalis
}

\author{
H. Bohne' ${ }^{1}$ J. Wanjiku¹, A.-K. Rathke², S. Humpert ${ }^{3}$ and D. Gerhard ${ }^{4}$ \\ ${ }^{1}$ Institute of Horticultural Production Systems, Section Woody Plant and Propagation Physiology, Leibniz University of \\ Hannover, Hannover, Germany \\ 2 Sarstedt, Germany \\ ${ }^{3}$ Lautenthal, Germany \\ ${ }^{4}$ School of Mathematics and Statistics, University of Canterbury, Christchurch, New Zealand
}

\section{Summary}

Nutrient loading applies more fertilizer compared to non-loading. Conventional loading delivers nutrients to the plants in a more or less constant rate mainly using slow release fertilizer; for exponential loading liquid fertilizer is used increasing exponentially towards the end of the vegetation period. Nutrient loading aims to build nutrient reserves, especially $\mathrm{N}$, in the plants to improve transplanting success. Until now the effect of this fertilization technique on abiotic stress reactions is not known. The reactions of Rosa majalis cultivated for one vegetation period (2010) without loading and with conventional or exponential loading were investigated in early frost (autumn 2010), late frost and drought (spring resp. summer 2011) under controlled conditions. In all treatments, the absolute level of damage, relative electrolyte leakage (REL), was low in early frost. However, relative electrolyte leakage significantly increased at $-8^{\circ} \mathrm{C}$ for the exponentially loaded plants while this was the case only at $-16^{\circ} \mathrm{C}$ for the conventionally loaded and non-loaded plants. Similarly for late frost, REL increased already at $-5^{\circ} \mathrm{C}$ for the exponentially loaded plants and only at $-9^{\circ} \mathrm{C}$ for the non-loaded and conventionally loaded ones. At $-5^{\circ} \mathrm{C}$ the absolute level of damage was low for plants from all treatments and high for $-9^{\circ} \mathrm{C}$. In both frost experiments, possible cryoprotective compounds like sucrose and glucose in most cases did not differ between the previous fertilization treatments.

However, concerning drought reactions, exponentially loaded plants had an advantage compared over conventionally loaded and nonloaded ones in postponing wilting. They closed their stomata earlier and synthesised highest concentrations of proline and sucrose compared to non-loaded and conventionally loaded plants. Possible reasons are discussed. The results indicate that the technique of exponential nutrient loading might be helpful to improve the plants' ability to perform well after being transplanted to drought prone sites. However, increased frost sensitivity has to be considered as well.

Keywords

glucose, proline, relative electrolyte leakage, stomatal conductance, sucrose, stress tolerance

\section{Significance of this study}

\section{What is already known on this subject?}

- Nutrient loading is a fertilization technique known to build up reserves in the plant without increasing its size during the nursery phase. The aim is to improve outplanting performance. After outplanting, depending on the site, different stresses affect the plants. The influence of the nutritional state of the plant on frost and drought is a matter of controversy.

\section{What are the new findings?}

- Although on a low level, damage after early and late frost of exponentially loaded Rosa majalis was higher compared to conventionally loaded and non-loaded plants. Drought tolerance was improved in the exponentially loaded plants.

What is the expected impact on horticulture?

- Nursery growing regimes influence plants attributes and subsequent performance when exposed to frost and drought stress.

\section{Introduction}

Nutrient loading is a fertilization concept with the aim to increase the N-, P-, and K-concentration in the plant without changing its size (Salifu and Timmer, 2003; Salifu et al., 2009). It can be carried out as conventional and exponential methods, which differ in the delivery schedule of nutrients. For exponential loading, the supply of nutrients increases exponentially during the vegetation period. While benefits of nutrient loading for outplanting performance are often documented in the literature, there is no information on the influence of stress reactions. High fertilization in the nursery can lead to reduced drought tolerance (Tan and Hogan, 1997). Concerning frost tolerance there are diverging opinions ranging from no influence (Thomas and Ahlers, 1999) to increased frost tolerance (Taulavori et al., 2001) and decreased frost tolerance (Jalkanen et al., 1998). Drought and frost stress reactions of systematically loaded plants, either conventionally or exponentially, are not known. Hence, conventional and exponential loaded Rosa majalis, which did not show differences in growth one year after outplanting in the landscape (non-fertilized soil, precipitation $633 \mathrm{~mm} \mathrm{a}^{-1}$, mean temperature in the growing season $15.5^{\circ} \mathrm{C}$ ) (Bohne et al., 2014), were tested under harsh and defined conditions for their frost and drought tolerance. Rosa majalis was chosen as an example for a plant used in the landscape. 


\section{Materials and methods}

\section{Cultivation of non-loaded and loaded plants}

One year old seedlings of Rosa majalis bought from a nursery were cultivated from April to end of October 2010 in 3-L containers on a container area using white peat (little decomposed white peat, peat fibre, $1 \mathrm{~g} \mathrm{~N}-$, P-, K-fertilizer $\mathrm{L}^{-1}, \mathrm{pH} 5.5$ ) as growing medium. Related to $\mathrm{N}$, the following fertilization treatments were applied: non-loading $0.8 \mathrm{~g} \mathrm{~N}$ $\mathrm{L}^{-1}$ (K8), conventional loading $2.4 \mathrm{~g} \mathrm{~N} \mathrm{~L}^{-1}$ (K24), exponential loading $2.4 \mathrm{~g} \mathrm{~N} \mathrm{~L}^{-1}$ (E24). Conventional fertilization was carried out using a slow release fertilizer (5-6 M; $15 \%$ $\mathrm{N}, 9 \% \mathrm{P}_{2} \mathrm{O}_{5}, 12 \% \mathrm{~K}_{2} \mathrm{O}, 2 \% \mathrm{MgO}$, micronutrients), which was added to the growing medium at potting. For the exponential loading a liquid fertilizer $\left(15 \% \mathrm{~N}, 10 \% \mathrm{P}_{2} \mathrm{O}_{5}\right.$, $15 \% \mathrm{~K}_{2} \mathrm{O}, 2 \% \mathrm{MgO}$, micronutrients) was used. For this treatment an exponentially increasing amount of fertilizer was supplied with an interval of three weeks (totally eight times during the vegetation period of 154 days), starting at potting in April. A detailed description is given in Bohne et al. (2014).

\section{Early and late frost experiment}

Hardening of the plants took place on the container area until the middle of December 2010. After this, plants were moved into a foil house for overwintering. At the end of February 2011, the foil house was kept open. The early frost experiment was carried out from 8-16 November 2010. In spring 2011 (10-15 April) the plants were subjected to a late frost experiment. The frost experiments with 9 plants per treatment took place in climate chambers (Vötsch Industrietechnik, VTZ 3008/S) under controlled conditions. Plants of the controls were exposed to $5^{\circ} \mathrm{C}$. In the early frost experiment this year's shoots (after bud set) were used; the air temperatures were $-16^{\circ} \mathrm{C}$ and $-8^{\circ} \mathrm{C}$. In the late frost experiment leaves were tested at an air temperature of $-9^{\circ} \mathrm{C}$ and $-5^{\circ} \mathrm{C}$. Temperature decrease and increase was $5^{\circ} \mathrm{C} \mathrm{h}^{-1}$. The treatment temperatures lasted for 8 hours. Samples were taken from the three longest shoots of each plant immediately after freezing. The damage due to frost was measured with the relative electrolyte leakage method (REL) (McKay, 1992; Schüte and Sarvas, 1999). In the early frost experiment, the uppermost $3 \mathrm{~cm}$ of the shoots were used; in the late frost experiment the uppermost three leaves. The shoot part beneath the $3 \mathrm{~cm}$ tip was used for the analysis of possible cryoprotective compounds like sucrose and glucose. In the late frost test 3-5 leaves beneath the upper ones were taken. Sucrose was determined using the microplate enzymatic essay (Zhao et al., 2010). Absorbance of each well was taken at $340 \mathrm{~nm}$ with an Epoch ${ }^{\circledR}$ Micro-Volume Spectrophotometer System. In the early frost experiment this year's shoots and in the late frost experiment leaves of the control plants were analyzed for $\mathrm{N}$ by controlled burning at $900^{\circ} \mathrm{C}$ using Vario MAX CN analyzer (Elementaranalysensysteme $\mathrm{GmbH}$ ).

\section{Drought experiment}

In summer 2011 the plants were subjected to drought under controlled conditions in a greenhouse by withdrawing irrigation. Control plants were irrigated by ebb and flow irrigation. Control plants and stress plants were arranged in a completely randomized design with 6 plants per treatment. Plants to be stressed stood on a spacer not to have contact with the irrigation water. During the drought period, stomatal conductance was measured daily on different three randomly chosen plants on leaves of three shoots per plant using an AP 4 porometer from Delta $\mathrm{T}$ Devices. All measurements were taken on the second or third fully developed leaf between 9 and 10 am on the respective days. The drought period was terminated when $50 \%$ of the plants in each treatment had severely wilted by visual symptoms (drooping of shoot tips and curling of leaves). At the end of the drought period leaf and root samples were taken from all stressed and control plants for the analysis of relative water content, sucrose, glucose and proline. Care was taken to get comparable samples regarding the position of leaves and the diameter of roots for all plants. Relative water content was measured from fresh weight, turgid weight and dry weight of the leaves. For proline analysis, a protocol from Bates (1973) was used. Absorbance of the cuvettes was determined with a photometer at $520 \mathrm{~nm}$. Analyses of sucrose, glucose and $\mathrm{N}$ were carried out as described in the frost experiment. Dry matter was determined at $70^{\circ} \mathrm{C}$.

\section{Statistical analysis}

The statistical analysis was carried out using R 2.1.5.1 (R Development Core Team, 2011). A linear mixed-effects model was assumed (Bates et al., 2011) estimating the effects of temperature and fertilization treatments under consideration of the repeated measurement structure per plant. Based on model diagnostics, the observations of relative electroly te leakage, cryoprotective compounds and $\mathrm{N}$ were log-transformed. The logarithmic transformation was performed to obtain approximate Gaussian distributed residuals with a common variance. Hypotheses tests were performed for all pairwise comparisons of treatment means after having carried out an ANOVA. P-values were adjusted according to Hothorn et al. (2008) at a global type-I-error level of $p \leq 0.05$. Stomatal conductance was not evaluated statistically since the measurement took place only on 3 out of 6 plants per treatment, choosing repeatedly a new random sample of plants during the course of the experiment.

\section{Results}

\section{Early frost experiment}

Freezing to $-8^{\circ} \mathrm{C}$ caused damage only for the exponentially loaded plants (E24) as indicated by REL. For these plants REL did not increase further at $-16^{\circ} \mathrm{C}$, whereas it did for the non-loaded (K8) and conventionally loaded (K24) ones. At this temperature, there were no differences in terms of REL between the fertilization treatments (Table 1). Proline (data not shown) and sucrose (Table 1) concentrations did not increase due to the frost. Glucose concentration significantly increased at $-16^{\circ} \mathrm{C}$ for the non-loaded plants (K8) compared to the control. The non-loaded plants had a higher glucose concentration than the loaded ones, although this was significant only for the conventionally loaded ones (K24) (Table 1). This year's shoots of plants from both loading treatments had higher $\% \mathrm{~N}$ in dry matter than the non-loaded plants (Table 1 ).

\section{Late frost experiment}

At $-5^{\circ} \mathrm{C}$ the frost damage (REL) increased significantly for the exponentially loaded plants (E24), but not for the non-loaded and conventionally loaded ones. At $-9^{\circ} \mathrm{C}$ there was a further increase in REL for all fertilization treatments, which was most pronounced for the 
Table 1. Relative electrolyte leakage; sucrose, glucose and N (\% in dry matter) of differently fertilized Rosa majalis in this year's shoots in an early frost experiment resp. leaves in a late frost experiment. K8: conventional fertilization, K24: conventional loading, E24: exponential loading. Means \pm standard deviation, $n=6$. Different letters show significant differences for $p \leq 0.05$ for the early resp. late frost experiment: capitals between frost treatments, lower cases between fertilization treatments within a frost treatment.

\begin{tabular}{|c|c|c|c|c|c|c|}
\hline \multirow{2}{*}{$\begin{array}{l}\text { Experiment / Plant part } \\
\text { Temperature }\end{array}$} & \multicolumn{3}{|c|}{ Early frost / This year's shoots } & \multicolumn{3}{|c|}{ Late frost / Leaves } \\
\hline & $5^{\circ} \mathrm{C}$ & $-8^{\circ} \mathrm{C}$ & $-16^{\circ} \mathrm{C}$ & $5^{\circ} \mathrm{C}$ & $-5^{\circ} \mathrm{C}$ & $-9^{\circ} \mathrm{C}$ \\
\hline Fertilization treatment & \multicolumn{6}{|c|}{ Relative electrolyte leakage (\%) } \\
\hline K8 & $15.25 \pm 2.07 \mathrm{Aa}$ & $17.32 \pm 3.20 \mathrm{Aa}$ & $26.48 \pm 3.23 \mathrm{Ba}$ & $8.19 \pm 1.51 \mathrm{Aa}$ & $9.64 \pm 2.34 \mathrm{Aab}$ & $37.01 \pm 14.57 \mathrm{Bab}$ \\
\hline K24 & $14.59 \pm 2.82 \mathrm{Aa}$ & $21.27 \pm 5.00 \mathrm{Aab}$ & $37.75 \pm 7.09 \mathrm{Ba}$ & $8.92 \pm 0.97 \mathrm{Aa}$ & $9.85 \pm 2.25 \mathrm{Aa}$ & $39.75 \pm 20.78 \mathrm{Ba}$ \\
\hline \multirow[t]{2}{*}{ E24 } & $16.63 \pm 5.32 \mathrm{Aa}$ & $26.26 \pm 13.59 \mathrm{Bb}$ & $31.45 \pm 5.74 \mathrm{Ba}$ & $9.04 \pm 2.16 \mathrm{Aa}$ & $14.36 \pm 4.15 \mathrm{Bb}$ & $51.11 \pm 7.35 \mathrm{Cb}$ \\
\hline & \multicolumn{6}{|c|}{ Sucrose $(\%$ in $\mathrm{dm})$} \\
\hline K8 & $3.20 \pm 0.67 \mathrm{Aa}$ & $3.26 \pm 0.69 \mathrm{Aa}$ & $3.30 \pm 1.22 \mathrm{Aa}$ & $5.02 \pm 1.45 \mathrm{Aba}$ & $6.33 \pm 2.94 \mathrm{Aa}$ & $2.52 \pm 1.04 \mathrm{Ba}$ \\
\hline K24 & $3.05 \pm 0.70 \mathrm{Aa}$ & $2.91 \pm 0.96 \mathrm{Aa}$ & $2.26 \pm 0.50 \mathrm{Aa}$ & $6.44 \pm 0.95 \mathrm{Aa}$ & $5.28 \pm 0.85 \mathrm{Aa}$ & $4.63 \pm 2.05 \mathrm{Aa}$ \\
\hline \multirow[t]{2}{*}{ E24 } & $3.31 \pm 0.47 \mathrm{Aa}$ & $2.21 \pm 0.57 \mathrm{Aa}$ & $2.48 \pm 0.80 \mathrm{Aa}$ & $4.99 \pm 2.09 \mathrm{Aa}$ & $5.05 \pm 1.43 \mathrm{Aa}$ & $4.22 \pm 2.08 \mathrm{Aa}$ \\
\hline & \multicolumn{6}{|c|}{ Glucose $(\%$ in $\mathrm{dm})$} \\
\hline K8 & $0.41 \pm 0.19 \mathrm{Aa}$ & $0.91 \pm 0.68 \mathrm{ABa}$ & $1.18 \pm 0.40 \mathrm{Ba}$ & $1.17 \pm 0.65 \mathrm{Aa}$ & $1.55 \pm 0.93 \mathrm{ABa}$ & $2.60 \pm 0.43 \mathrm{Ba}$ \\
\hline K24 & $1.05 \pm 0.27 \mathrm{Ab}$ & $0.65 \pm 0.24 \mathrm{Ba}$ & $0.99 \pm 0.16 \mathrm{ABb}$ & $1.41 \pm 0.47 \mathrm{Aa}$ & $1.32 \pm 0.63 \mathrm{Aa}$ & $2.10 \pm 1.13 \mathrm{Aa}$ \\
\hline \multirow[t]{2}{*}{ E24 } & $0.64 \pm 0.14 \mathrm{Aab}$ & $0.81 \pm 0.19 \mathrm{Aa}$ & $1.00 \pm 0.11 \mathrm{Aab}$ & $1.40 \pm 0.62 \mathrm{Aa}$ & $1.66 \pm 0.54 \mathrm{Aa}$ & $3.19 \pm 1.11 \mathrm{Ba}$ \\
\hline & \multicolumn{6}{|c|}{$\mathrm{N}(\%$ in $\mathrm{dm})$} \\
\hline K8 & $1.25 \pm 0.17 \mathrm{a}$ & & & $3.51 \pm 0.62 \mathrm{a}$ & & \\
\hline K24 & $3.09 \pm 0.26 b$ & & & $4.70 \pm 0.39 b$ & & \\
\hline E24 & $2.27 \pm 0.16 \mathrm{c}$ & & & $4.70 \pm 0.32 b$ & & \\
\hline
\end{tabular}

exponentially loaded plants. Within each frost temperature the exponentially loaded plants showed the highest REL, though not statistically different from the non-loaded plants (Table 1). Apart from a decrease in the non-loaded plants at $-9^{\circ} \mathrm{C}$ there were no significant effects of the frost and fertilization treatments on the sucrose concentration after frost (Table 1). Glucose significantly increased at $-9^{\circ} \mathrm{C}$ for the non-loaded (K8) and the exponentially loaded (E24) plants. For a given temperature, glucose concentration was not significantly influenced by the fertilization (Table 1). Proline was not investigated in the late frost experiment, as it did not show any reactions during early frost. Leaves of plants from both loading treatments had higher $\% \mathrm{~N}$ in dry matter compared to those from the non-loaded plants (Table 1).

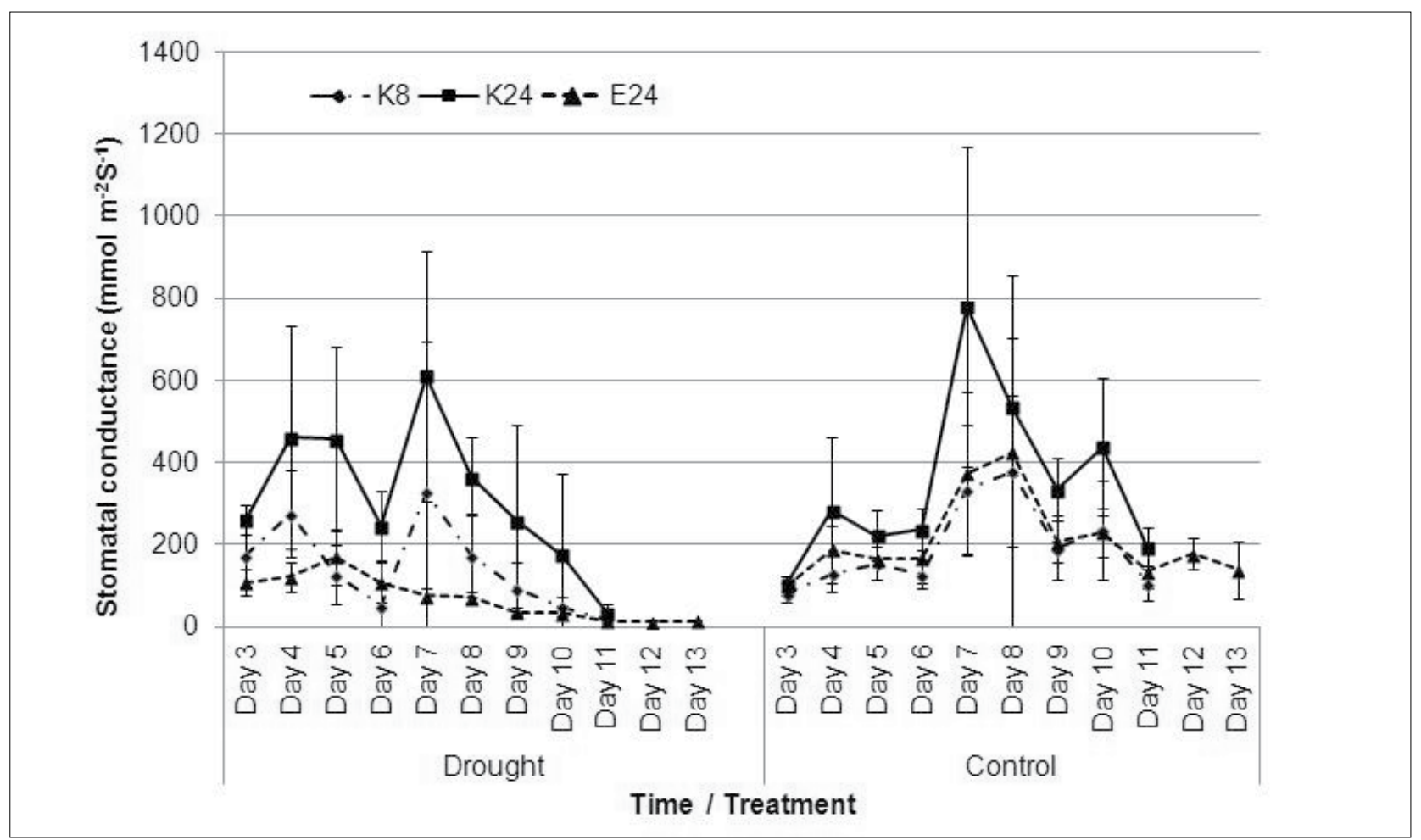

Figure 1. Stomatal conductance $\left(\mathrm{mmol} \mathrm{m}^{-2} \mathrm{~s}^{-1}\right)$ of differently fertilized Rosa majalis in a drought experiment. K8: conventional fertilization, K24: conventional loading, E24: exponential loading. Means \pm standard deviation, $n=3$. 
Table 2. Concentration of proline ( $\mu \mathrm{g} \mathrm{g} \mathrm{g}^{-1}$ dry matter), sucrose and glucose (mg g-1 dry matter) of differently fertilized Rosa majalis in leaves and roots in a drought experiment. K8: conventional fertilization, K24: conventional loading, E24: exponential loading. Means \pm standard deviation, $n=6$. Different letters show significant differences for $p \leq 0.05$ : capitals between drought and control, lower cases between fertilization treatments within drought resp. control.

\begin{tabular}{|c|c|c|c|c|}
\hline \multirow{2}{*}{$\begin{array}{l}\text { Plant part } \\
\text { Stress treatment }\end{array}$} & \multicolumn{2}{|c|}{ Leaves } & \multicolumn{2}{|c|}{ Roots } \\
\hline & Drought & Control & Drought & Control \\
\hline Fertilization treatment & \multicolumn{4}{|c|}{ Proline ( $\left.\mu \mathrm{g} \mathrm{g}^{-1} \mathrm{dm}\right)$} \\
\hline K8 & $304.0 \pm 154 \quad \mathrm{Ba}$ & $64.1 \pm 3.2 \mathrm{Aa}$ & $231.5 \pm 132.8 \mathrm{Bb}$ & $59.8 \pm 5.2 \mathrm{Aa}$ \\
\hline K24 & $164.0 \pm 192.2 \mathrm{Ba}$ & $66.2 \pm 3.1 \mathrm{Aa}$ & $212.1 \pm 136.0 \mathrm{Ba}$ & $68.5 \pm 6.9 \mathrm{Aa}$ \\
\hline \multirow[t]{2}{*}{ E24 } & $2948.2 \pm 540 \mathrm{Bb}$ & $63.6 \pm 9.7 \mathrm{Aa}$ & $644.9 \pm 418.5 \mathrm{Bb}$ & $68.8 \pm 8.0 \mathrm{Aa}$ \\
\hline & \multicolumn{4}{|c|}{ Sucrose (mg g-1 dm) } \\
\hline K8 & $6.95 \pm 1.43 \mathrm{Aa}$ & $6.77 \pm 0.91 \mathrm{Aab}$ & $4.42 \pm 0.72 \mathrm{Ba}$ & $2.29 \pm 0.58 \mathrm{Aa}$ \\
\hline K24 & $6.12 \pm 1.87 \mathrm{Aa}$ & $6.61 \pm 1.47 \mathrm{Aa}$ & $3.71 \pm 1.67 \mathrm{Aa}$ & $2.36 \pm 0.23 \mathrm{Aa}$ \\
\hline \multirow[t]{2}{*}{ E24 } & $9.84 \pm 1.73 \mathrm{Bb}$ & $7.53 \pm 1.05 \mathrm{Ab}$ & $8.36 \pm 3.98 \mathrm{Bb}$ & $2.44 \pm 0.78 \mathrm{Aa}$ \\
\hline & \multicolumn{4}{|c|}{ Glucose (mg g-1 dm) } \\
\hline K8 & $0.43 \pm 0.37 \mathrm{Aa}$ & $0.14 \pm 0.25 \mathrm{Aa}$ & $1.28 \pm 0.44 \mathrm{Ba}$ & $0.45 \pm 0.15 \mathrm{Aa}$ \\
\hline K24 & $0.74 \pm 0.17 \mathrm{Ba}$ & $0.06 \pm 0.07 \mathrm{Aa}$ & $1.45 \pm 0.38 \mathrm{Ba}$ & $0.55 \pm 0.17 \mathrm{Aa}$ \\
\hline E24 & $0.33 \pm 0.30 \mathrm{Ba}$ & $0.07 \pm 0.17 \mathrm{Aa}$ & $1.87 \pm 0.38 \mathrm{Ba}$ & $0.61 \pm 0.12 \mathrm{Aa}$ \\
\hline
\end{tabular}

\section{Drought experiment}

When exposed to drought in 2011 (following the year with different fertilization treatments, 2010), exponentially loaded plants (E24) closed stomata earlier and wilted later compared to the conventionally loaded (K24) and nonloaded (K8) ones (Figure 1). Drought stress provoked a significant increase in the proline concentration both in leaves and roots with plants from the exponential loading treatment showing significantly higher concentrations than the non-loaded and conventionally loaded ones (Table 2). Sucrose increased significantly due to drought in the exponentially loaded plants both in leaves and roots and in the non-loaded plants in roots. Again the exponentially loaded plants had the highest concentration. In the roots, drought caused glucose to rise independent of the fertilization, while in the leaves this happened only for both loading treatments.

There was significant reduction in shoots growth and partly of roots (K24) due to drought (Table 3). At the end of the drought period dry matter content of this year's shoots and roots was highest for previously non-loaded plants, though not statistically different for roots. In the irrigated control, growth of this year's shoots and roots did not differ significantly between the fertilization treatments. There was no effect of drought (apart from K8 plants) and fertilization in 2010 on the concentration of $\mathrm{N}$ in the dry matter of leaves (Table 3). This was also the case for $\mathrm{P}$ and $\mathrm{K}$ (data not shown).

\section{Discussion}

\section{Early and late frost experiment}

The relative electrolyte leakage (REL) is a measure for injured cell membranes, which release their electrolytes into the surrounding medium (Sutinen et al., 1992). From our results control plants (non-injured cells), had some leakage (Table 1), a scenario which has been reported by other authors. Schüte and Sarvas (1999) reported a 15\% REL of the root neck for non-stressed Quercus robur; for this year's shoots of Salix cinerea Selig et al. (2011) found similar results (approx. 19\% REL). In exponentially loaded plants there was an increase in REL with frost treatment until $-8^{\circ} \mathrm{C}$. Direct comparisons of REL with effective damage of plant organs are scarce. According to Schüte and Sarvas (1999), REL-data $>40 \%$ from the root neck of stressed seedlings of Quercus robur indicated terminal buds failure to sprout. The results presented here are below this range, indicating minor damage. This agrees with the popular scientific description of Rosa majalis being very frost hardy in winter (i.e., www.infoflora.ch/) and can also explain, why cryoprotective compounds like proline and sucrose are not or in the case of glucose only partly $\left(\mathrm{K} 8,-16^{\circ} \mathrm{C}\right)$ synthesized. Although the damage is on low level, REL-data for the loaded plants are higher than for the non-loaded ones being significant for the exponentially loaded plants at $-8^{\circ} \mathrm{C}$. This might be due to the higher $\mathrm{N}$-concentration in this year's shoots of these plants (Table 1). In the literature

Table 3. Dry matter (g plant ${ }^{-1}$ ) of this year's shoots and roots and $\mathrm{N}$ in leaves (\% in dry matter) of differently fertilized Rosa majalis in a drought experiment. K8: conventional fertilization, K24: conventional loading, E24: exponential loading. Means \pm standard deviation, $n=6$. Different letters show significant differences for $p \leq 0.05$ : capitals between drought and control, lower cases between fertilization treatments within drought resp. control.

\begin{tabular}{lcccccc}
\hline Plant part & \multicolumn{2}{c}{ This year's shoots } & \multicolumn{2}{c}{ Roots } & \multicolumn{2}{c}{ Leaves } \\
\hline Stress treatment & Drought & Control & Drought & Control & Drought & Control \\
\hline Fertilization treatment & & \multicolumn{2}{c}{ Dry matter $(g$ plant-1) } & & $\% \mathrm{~N}$ in dry matter \\
K8 & $65 \pm 19 \mathrm{Ab}$ & $89 \pm 16 \mathrm{Ba}$ & $72 \pm 34 \mathrm{Aa}$ & $146 \pm 50 \mathrm{Aa}$ & $1.95 \pm 0.11 \mathrm{Aa}$ & $1.66 \pm 0.08 \mathrm{Ba}$ \\
K24 & $41 \pm 13 \mathrm{Aa}$ & $95 \pm 31 \mathrm{Ba}$ & $39 \pm 32 \mathrm{Aa}$ & $125 \pm 63 \mathrm{Ba}$ & $1.92 \pm 0.20 \mathrm{Aa}$ & $1.76 \pm 0.10 \mathrm{Aa}$ \\
E24 & $59 \pm 11 \mathrm{Aa}$ & $93 \pm 33 \mathrm{Ba}$ & $53 \pm 13 \mathrm{Aa}$ & $132 \pm 64 \mathrm{Aa}$ & $1.74 \pm 0.13 \mathrm{Aa}$ & $1.69 \pm 0.14 \mathrm{Aa}$ \\
\hline
\end{tabular}


the results concerning the influence of high fertilization on frost hardiness are not consistent; both an increase (Rikala and Repo, 1997) and a decrease (Scagel et al., 2010) are reported. Concerning nutrient loading, Miller et al. (1995) in Timmer and Aidelbaum (1996) found for white spruce no difference between conventionally and exponentially loaded plants. The synthesis of proline, which is known as a cryoprotective compound (Kuznetsov and Shevyakova, 1999) is influenced by N-fertilization. Sanchez et al. (2002) found an increase with increasing $\mathrm{N}$-fertilization. This did not happen in the loading treatments of this experiment. Decreasing frost tolerance of high fertilized plants often is attributed to continued growth and delayed hardening (Bigras et al., 1996), which results in higher water content of the plant organs and thus makes them more susceptible to frost.

Similar to the early frost experiment, when exposed to late frost REL of exponentially loaded plants already increased at a lower degree of frost $\left(-5^{\circ} \mathrm{C}\right)$. The level of REL is low. Decreasing the temperature to $-9^{\circ} \mathrm{C}$ increased REL of plants in all treatments, again being most pronounced for the exponentially loaded plants. Comparable to the early frost treatment there were no clear influences of the fertilization treatments on the concentration of sucrose and glucose. Higher $\mathrm{N}$-concentration in the leaves of the loaded compared to the non-loaded plants can be due to remobilization of higher N-reserves of these plants (Salifu and Timmer, 2003). It is reported that plants with high $\mathrm{N}$-concentration may deharden earlier than those with lower N-concentration (Fløistad and Kohmann, 2004; Sennerby-Forsse and von Fircks, 1987). The latter two demonstrated that actively growing shoots have enlarged intercellular spaces in which at freezing large ice crystals are formed and damage cells. Observation of the plants in the experiment reported here showed an earlier bud break of the exponentially loaded plants compared to the conventionally loaded and to the non-loaded ones.

Summing up, for Rosa majalis the nutrient loading treatments slightly increased freezing injuries in autumn (November) and in spring (April). This may be due to increased $\mathrm{N}$-concentration, which could have influenced processes of hardening and dehardening in the loaded plants. However, detailed phenological studies were not carried out. The fertilization treatments had no coherent influence on the investigated cryoprotective compounds. The function of other sugars or $\mathrm{K}$ with regard to frost hardiness were not considered.

\section{Drought experiment}

Surprisingly, plants exponentially loaded (E24) in 2010 - though similar in size - wilted later and at lower relative water content (data not shown) than the non-loaded ones. This was due to a faster closure of stomata (Figure 1), very high concentrations of proline and high concentrations of sucrose (Table 2). Quick closure of stomata of exponentially loaded red pine seedlings was also found by Timmer and Aidelbaum (1996). Proline is known not only for its osmoregulatory effect but also for its ability to stabilize intact hydration layers and preserve spatial structures in dehydrating cells (Kuznetsov and Shevyakova, 1999). The reason for the high increase in proline in the exponentially loaded plants upon drought could only be speculated. It is known that the $\mathrm{N}$-supply influences the synthesis of proline (Sanchez et al., 2002), but in $2011 \mathrm{~N}$-concentrations in the leaves did not differ between the fertilization treatments in 2010 (Table 3). However, remobilized N from last year's shoots and roots might have been used for the synthesis of proline. $\mathrm{N}$ from previous exponential fertilization is more easily remobilized compared to $\mathrm{N}$ from conventional fertilization (Timmer, 1996). The fast response of stomata probably could not have been due to different sensing of decreasing water supply from the roots since there was no significant difference in the dry matter of roots between exponentially loaded and non-loaded plants (Table 3). Although emphasising that there is no obligate role for nitrate/CHL1 in stomatal functioning, Guo et al. (2003) found out that stomatal conductance for Arabidopsis was mediated by a nitrate transporter (CHL1) and was higher in the presence of nitrate in the growing medium. This agrees with the findings from Villar-Salvador (2005) who reported high stomatal conductance of highly fertilized $\left(\mathrm{NH}_{4} \mathrm{NO}_{3}\right)$ Pinus pinea and Pinus halepensis. Assuming the exponentially loaded plants in our experiment used more stored and remobilized $\mathrm{N}$ than $\mathrm{N}$ from the fertilizer $\left(\mathrm{NH}_{4}-\mathrm{N}\right.$ and $\mathrm{NO}_{3}-\mathrm{N}$ ) there might be an interesting relation between $\mathrm{N}$-reserves in the plant and quick stomatal response to water deficits. This is supported by the behaviour of the plants conventionally loaded (K24) in 2010, which - compared to the exponentially loaded ones - had a higher stomatal conductance and a much smaller increase in proline in their leaves when exposed to drought. In contrast to the exponentially loaded plants, which received more fertilizer at the end of the growing season, these plants were fertilized with a constant supply during the growing season 2010. But this aspect needs more detailed investigation, since we could not differentiate between remobilized $\mathrm{N}$ and $\mathrm{N}$ taken up from the fertilizer given in 2011.

In 2011, dry matter of new shoots and roots did not differ between the fertilization treatments from 2010, as also reported in Bohne et al. (2014) for plants outplanted in the landscape. At the end of a period of controlled drought of 11 (K8, K24) or 13 (E24) days dry matter content of new shoots and roots - although not always significant for roots - was smaller for the stressed compared to the non-stressed plants. Plants adjusted their growth to the decreasing amount of available water and this was more pronounced for the plants loaded in 2010 (K24, E24) than for the non-loaded ones (K8). Non-loaded plants had the highest dry matter content of roots, which probably delivered enough water to the shoots for a prolonged time, hence the smaller reduction in shoot growth. Root growth is a well-known strategy to cope with limited water resources (Grossnickle, 2005; Padilla and Pugnaire, 2007) leading to stress-avoidance during temporary water shortage. Although stomatal conductance of non-loaded plants - similarly a trait of stress avoidance - decreased, visible wilting occurred after 6 days, which did not happen for plants from the other treatments. There was some osmotic adjustment in terms of increased concentration of proline, sucrose and glucose in roots and of proline in leaves, but this could not satisfy the transpiration demand of the plants under conditions of further decreasing water supply. In contrast, this had been possible for the exponentially loaded plants which exhibited both stress avoidance in terms of decreasing stomatal conductance as well as stress tolerance by producing very high concentrations of the multifunctional amino acid proline and thus postponing wilting. 


\section{Conclusion}

While no differences on outplanting performance at the end of the vegetation period of non-loaded and loaded plants were observed (Bohne et al., 2014), reactions on defined and obvious frost and drought stress occurred. Concerning early and late frost, sensitivity increased in the previously loaded plants, though for early frost $\left(-8^{\circ} \mathrm{C}\right.$ and $\left.-16^{\circ} \mathrm{C}\right)$ and mild late frost $\left(-5^{\circ} \mathrm{C}\right.$ compared to $\left.-9^{\circ} \mathrm{C}\right)$ on a low absolute level. High freezing tolerance probably is a specific trait of Rosa majalis and is different for other species. Drought tolerance was highly increased for the previously exponentially loaded plants due to improved physiological attributes which included both stress avoidance and stress tolerance. Considering the reactions upon frost as well as on drought it turns out that benefits of nutrient loading must not be generalized but depend on the kind and degree of stresses the plants encounter on their specific site after outplanting.

\section{References}

Bates, L.S. (1973). Rapid determination of free proline for water stress studies. Plant and Soil 39, 205-207. http://dx.doi. org/10.1007/BF00018060.

Bates, D., Maechler, M., and Bolker, B. (2011). lme4: Linear mixedeffects models using S4 classes. R package version 0.999375-42. http://CRAN.R-project.org/package=lme4.

Bigras, F.J., Gonzalez, A., d'Aoust, A.L., and Hébert, C. (1996). Frost hardiness, bud phenology and growth of containerized Picea mariana seedlings grown at three nitrogen levels and three temperature regimes. New Forests 12, 243-259.

Bohne, H., Wanjiku, J., Rathke, A.-K., Humpert, S., and Gerhard, D. (2014). Influence of nutrient loading on growth, N-, P- and K-concentrations and outplanting performance of Rosa majalis. Europ. J. Hort. Sci. 79(1), 29-35.

Fløistad, I.S., and Kohmann, K. (2004). Influence of nutrient supply on spring frost hardiness and time of bud break in Norway spruce (Picea abies (L.) Karst.) seedlings. New Forests 27, 1-11. http:// dx.doi.org/10.1023/A:1025085403026.

Grossnickle, S.C. (2005). Why seedlings survive: influence of plant attributes. New Forests 43, 711-738. http://dx.doi.org/10.1007/ s11056-012-9336-6.

Guo, F.Q., Young, J., and Crawford, N.M. (2003). The nitrate transporter AtNRT1.1 (CHL1) functions in stomatal opening and contributes to drought susceptibility in Arabidopsis. The Plant Cell 15, 107-117. http://dx.doi.org/10.1105/tpc.006312.

Hothorn, T., Bretz, F., and Westfall, P. (2008). Simultaneous inference in general parametric models. Biometrical Journal 50(3), 346-363. http://dx.doi.org/10.1002/bimj.200810425.

Jalkanen, R.E., Redfern, D.B., and Sheppard, L.J. (1998). Nutrient deficits increase frost hardiness in Sitka spruce (Picea sitchensis) needles. For. Ecol. Manag. 107, 191-201. http://dx.doi.org/10.1016/ S0378-1127(97)00338-1.

Kuznetsov, V.V., and Shevyakova, N.I. (1999). Proline under stress: biological role, metabolism, and regulation. Russ. J. Plant Physiol. $46,274-289$.

McKay, H.M. (1992). Electrolyte leakage from fine roots of conifer seedlings: a rapid method of plant vitality following cold storage. Can. J. For. Res. 22, 1371-1377. http://dx.doi.org/10.1139/x92-182.

Miller, B.D., Timmer, V.R., Staples, C., and Farintosh, L. (1995). Exponential fertilization of white spruce greenhouse transplants at Orono Nursery. In Manual for exponential nutrient loading of seedlings to improve outplanting performance on competitive forest sites. NODA/NFP Technical report; TR-25, V.R. Timmer and A.S. Aidelbaum, eds. (Toronto, ON.: Queen's Printers for Ontario, Nursery Notes No. 130), 13 pp.

Padilla, F.M., and Pugnaire, F.I. (2007). Rooting depth and soil moisture control Mediterranean woody seedling survival during drought. Funct. Ecol. 21, 489-495. http://dx.doi.org/10.1111/ j.1365-2435.2007.01267.x.

R Development Core Team. (2011). R: A language and environment for statistical computing. (Vienna, Austria: R Foundation for Statistical Computing). URL http://www.R-project.org/.

Rikala, R., and Repo, T.(1997).The effect of late summer fertilization on the frost hardening of second-year Scots pine seedlings. New Forests 14, 33-44. http://dx.doi.org/10.1023/A:1006505919556.

Salifu, K.F., Jacobs, D.F., and Birge, Z.K.D. (2009). Nursery nitrogen loading improves field performance of bareroot oak seedlings planted on abandoned mine lands. Restoration Ecology 17(3), 339-349. http://dx.doi.org/10.1111/j.1526-100X.2008.00373.x.

Salifu, K.F., and Timmer, V.R. (2003). Optimizing nitrogen loading of Picea mariana seedlings during nursery culture. Can. J. For. Res. 33, 1287-1294. http://dx.doi.org/10.1139/x03-057.

Sánchez, E., Garcia, P.C., López-Lefebre, L.R., Rivero, R.M., Manuel, J., and Romero, L. (2002). Proline metabolism in response to nitrogen deficiency in French bean plants (Phaseolus vulgaris $\mathrm{L}$. 'Strike'). Plant growth regulation 36(3), 261-265. http://dx.doi. org/10.1023/A:1016583430792.

Scagel, F.C., Regan, P.R., Hummel, R., and Bi, G. (2010). Cold tolerance of container-grown green ash is influenced by nitrogen fertilizer type and rate. HortTechnology 20(2), 292-303.

Schüte, G., and Sarvas, M. (1999). Elektrolytverlustmessung als Testmethode zur Vitalitätsbestimmung von Eichensämlingen (Quercus robur L.). Forstarchiv 70, 133-138.

Selig, M., Bohne, H., and Gerhard, D. (2011). Auswirkungen einer Nachdüngung im Sommer auf die Frosthärte von Salix cinerea L. sowie auf ausgewählte Nährstoffe und Biomarker. Gesunde Pflanzen 63, 129-133. http://dx.doi.org/10.1007/s10343-0110256-8.

Sennerby-Forsse, L., and Von Fircks, H.A. (1987). Ultrastructure of cells in the cambial region during winter harding and spring dehardening in Salix dasyclados Wimm. grown at two nutrient levels. Trees 1, 151-163. http://dx.doi.org/10.1007/BF00193558.

Sutinen, M.L., Palta, J.P., and Reich, P.B. (1992). Seasonal differences in freezing stress resistance of needles of Pinus nigra and Pinus resinosa: evaluation of the electrolyte leakage method. Tree Physiology 11, 241-254. http://dx.doi.org/10.1093/ treephys/11.3.241.

Tan, W., and Hogan, G.D. (1997). Physiological and morphological responses to nitrogen limitation in jack pine seedlings: potential implications for drought tolerance. New Forests 14, 19-31. http:// dx.doi.org/10.1023/A:1006546014858.

Taulavuori, K., Taulavuori, E., Niinimaa, A., and Laine, K. (2001). Acceleration of frost hardening in Vaccinium vitis-idaea by nitrogen fertilization. Oecologia 127(3), 321-323. http://dx.doi. org/10.1007/s004420100661.

Thomas, F.M., and Ahlers, U. (1999). Effects of excess nitrogen on frost hardiness and freezing injury of above-ground tissue in young oaks (Quercus petraea and Quercus robur). New Phytol. 144, 73-83. http://dx.doi.org/10.1046/j.1469-8137.1999.00501.x.

Timmer, V.R. (1996). Exponential nutrient loading: a new fertilization technique to improve seedling performance on competitive sites. New Forests 13, 275-295. 
Timmer, V.R., and Aidelbaum, A.S. (1996). Manual for exponential nutrient loading of seedlings to improve outplanting performance on competitive forest sites. NODA/NFP Technical report; TR-25.

Villar-Salvador, P., Puértolas, J., Penuelas, J.L., and Planelles, R. (2005). Effect of nitrogen fertilization on the drought and frost resistance of Mediterranean forest species. Invest. Agrar. Sist. Recur. For. 14(3), 408-418.

Zhao, D., MacKown, C.T., Starks, P.J., and Kindiger, B.K. (2010). Rapid analysis of nonstructural carbohydrate components in grass forage using microplate enzymatic assays. Crop Sc. 50(4), 1537-1545.

www.infoflora.ch/ ; download 25 July 2014.

Received: Aug. 3, 2014

Accepted: Mar. 10, 2015

Addresses of authors:

H. Bohne1,*, J. Wanjiku1 ${ }^{1}$ A.-K. Rathke 2 , S. Humpert ${ }^{3}$ and

D. Gerhard 4

${ }^{1}$ Institute of Horticultural Production Systems, Section

Woody Plant and Propagation Physiology, Leibniz

University of Hannover, Hannover, Germany

2 Lappenberg 12, 31157 Sarstedt, Germany

${ }^{3}$ Hahnenkleestr. 48, 38685 Lautenthal, Germany

${ }^{4}$ School of Mathematics and Statistics, University of

Canterbury, Private Bag 4800, Christchurch 8140,

New Zealand

*Corresponding author;

E-mail: bohne@baum.uni-hannover.de 